\title{
The state of international management research in South African management journals
}

\author{
Author: \\ Adolf J. Vögel ${ }^{1}$ \\ Affiliation: \\ ${ }^{1}$ Department of Business \\ Management, University of \\ Pretoria, South Africa \\ Correspondence to: \\ Johan Vögel \\ Email: \\ johan.vogel@up.ac.za \\ Postal address: \\ Private Bag X20, Hatfield \\ 0028, South Africa \\ Dates: \\ Received: 26 Mar. 2014 \\ Accepted: 30 Sept. 2014 \\ Published: 27 Feb. 2015 \\ How to cite this article: \\ Vögel, A.J., 2015, 'The state \\ of international management \\ research in South African \\ management journals', \\ Acta Commercii 15(1), Art. \\ \#262, 6 pages. http://dx.doi. \\ org/10.4102/ac.v15i1.262

\section{Copyright:} \\ (C) 2015. The Authors. \\ Licensee: AOSIS \\ OpenJournals. This work is \\ licensed under the Creative \\ Commons Attribution \\ License.
}

Read online:
Orientation: It is considered important to take stock periodically of the present channels available for communication of scholarly discourse and research, something that has not been done in international management in South Africa.

Research purpose: This study aimed to not only identify the gaps in South African international management research, but also to serve as a source of international management research with a South African focus in order to aid future South African international management research.

Motivation for the study: As South African business become more global and international management plays a more central role in business practice, the importance and relevance of international management increases, thus necessitating a greater research focus on international management.

Research design, approach and method: A content analysis was conducted on the 1313 articles published in the seven South African management journals between 2004 and 2013.

Main findings: Not only is a mere $2.7 \%$ of all articles published in the seven South African management journals between 2004 and 2013 focused on international management, but there was also a decline in the number of international management articles published.

Contributions/value-add: This study will not only help to identify the gaps in international management research in South Africa, but will also serve as a source of South African international management research for future researchers and academics.

\section{Introduction}

According to Holsapple et al. (1993:232), it is considered important to take stock periodically of the present channels - books, journal articles and conference proceedings - available for communicating scholarly discourse and research. When looking at international management (IM) research, this has been done internationally with Lu (2003) focusing on contributions and gaps in international strategic management research, Peng and Zhou (2006) looking at the impact and influence of global strategy research and Werner (2002) focusing on recent trends in IM research. Although these articles have given us a clearer understanding of the state of IM research internationally, very little is known about the state of IM research in South Africa.

\section{Setting}

\section{Background}

Since its re-emergence from political and economic isolation in the early 1990s, South Africa has steadily increased its international presence, to not only rank amongst the top 10 largest emerging-market investors by 2004 (United Nations Conference on Trade and Development [UNCTAD] 2005:3), but also to become the largest investor into the rest of Africa for the period 1990 to 2000 (LiquidAfrica, in South Africa Foundation 2004:13). At the beginning of 2005, 34 of the top 100 Johannesburg Securities Exchange (JSE) listed companies had 232 investment projects in 27 African countries, employing 71874 people (UNCTAD 2005:5). More recently, South Africa was listed as the largest source country of foreign direct investment (FDI) in Africa, with outflows of US\$4.4 billion in 2011 (UNCTAD 2013a), as well as being the second-biggest developing country source of FDI into Africa - as measured by stock of FDI (UNCTAD 2013b:40).

Exports of the South African Customs Union (SACU) to the rest of Africa have increased from just over R5 billion in 1991 to over R43 billion in 2002, before falling back to R38.4 billion in 2003, with South Africa accounting for about 80\% of the total (South Africa Foundation 2004:8). 


\section{Trends}

According to Werner (2002:277), as business becomes more global and IM issues play a more central role in business practice - as in the case of South Africa - the importance and relevance of IM research increases. However, the majority of the IM research originates in the United States of America (USA) and Western Europe (Kriek, Beaty \& Nkomo 2009:126; Lau 2002:171; Tsui 2004:492), whilst there is a lack of hard research in lesser developed countries (LDCs) in general, and in Africa, sub-Saharan Africa and South Africa in particular (Newa \& Fillippaios, in Oosthuizen 2005:77). This does not mean that these LDCs are less important in terms of IM research. According to Akbar and Samii (2005:389), emerging markets are an important testing ground for existing theories, models and concepts of business and management and can also offer an opportunity for developing new theoretical contributions in the fields of management and business studies.

\section{Objectives and contribution to the field}

Given the increasingly important international role played by South African firms, as well as the fact that no stocktake of the present channels available for communicating scholarly discourse and research on IM has been done in South Africa, the primary objectives of this article were, firstly, to identify the current state of IM research in South African management journals (2004-2013) and, secondly, to determine gaps in South African IM research so as to identify possible areas for future research.

\section{Research methods and design}

In identifying the IM research published in South African management journals over the last decade (2004-2013), this study focused on the seven South African management journals accredited by the South African Department of Higher Education and Training (Department of Higher Education and Training 2012), namely, Acta Commercii, Journal of Contemporary Management, Management Dynamics, South African Journal of Business Management, South African Journal of Economic and Management Sciences, SA Journal of Human Resource Management and Southern African Business Review. These journals were chosen because they were considered to have a South African focus; even though South African authors do publish in international journals, examples being Barnard (2008), Klein and Wöcke (2007), Luiz and Charalambous (2009) and Wöcke and Klein (2009), publishing in international journals is considered to be more difficult (Tsui 2004:491).

Reasons for this could be the perception of entry barriers created by disciplinary and paradigmatic preferences of gate-keepers of the leading international scholarly journals, as well as the continued dominance of IM scholarship by authors from North America (Kirkman \& Law, in Kriek et al. 2009:127). As a result, South African research is thought to be published predominantly in local journals. Although the place of publication of a journal is not a perfect indicator of the origin of the article, it can be seen as being a reasonable indicator of the type of research and source of data that are likely to be included (Tsui 2004:492).

The analysis of the content of the 1313 articles published in these seven journals over the last 10 years started with an analysis of the titles of the articles in order to exclude the purely domestic, non-IM, articles from the list. An example of such a title would be: The impact of hunting for biltong purposes on the SA economy (Saayman, Van der Merwe \& Rossouw 2011). If any doubt existed, the article would go through to the second round of analysis, during which the abstract of each article was analysed in an attempt to determine if it had an IM focus and, if so, under which IM topic it should be classified. The last round of the analysis involved all articles over which there was still doubt and involved a thorough analysis of the entire article.

Werner's (2002:280) 12 distinct IM topics were used as classification for this study (see Table 1); although Werner (2002:281) stated that his 12 IM topics should be treated as an organising tool rather than a definitive classification, redefining the topics of IM fell outside the scope of this study.

TABLE 1: International management classification topics.

\begin{tabular}{|c|c|}
\hline Topics & Sub-topics \\
\hline Global business environment & $\begin{array}{l}\text { This research topic includes studies on: the global economy; market structure; political and regulatory environment; and international } \\
\text { risk. }\end{array}$ \\
\hline Internationalisation & $\begin{array}{l}\text { This topic includes studies on: the description and measurement of internationalisation; antecedents of internationalisation; and } \\
\text { consequences of internationalisation. }\end{array}$ \\
\hline Entry-mode decisions & $\begin{array}{l}\text { Entry-mode decisions include: the predictors of entry-mode choices; predictors of international equity ownership levels; and } \\
\text { consequences of entry-mode decisions. }\end{array}$ \\
\hline International joint ventures & $\begin{array}{l}\text { The international joint ventures topic includes: motivations for international joint ventures (IJV) partner selection; IJV partner relations; } \\
\text { and consequences of IJVs. }\end{array}$ \\
\hline Foreign direct investment (FDI) & $\begin{array}{l}\text { This international management (IM) topic includes: timing of FDI; motivations for FDI; location of FDI; and enterprise and host country } \\
\text { consequences of FDI. }\end{array}$ \\
\hline International exchange & This topic includes: exchange overviews; determinants of exporting; export intermediaries; and consequences of exporting. \\
\hline Transfer of knowledge & $\begin{array}{l}\text { This area of IM research includes: antecedents of knowledge transfer; processes of knowledge transfer; and consequences of knowledge } \\
\text { transfers. }\end{array}$ \\
\hline Strategic alliances and networks & Strategic alliances and networks include: strategic alliance relationships; business networks; and outcomes of strategic alliances. \\
\hline Multinational enterprises (MNE) & The topic of multinational enterprises includes: MNE policies; MNE strategies; and models and descriptions of the MNE. \\
\hline Subsidiary-HQ relations & This IM topic includes: subsidiary role; subsidiary control; and subsidiary performance. \\
\hline Expatriate management & The last IM topic includes: expatriate HRM; issues of expatriates; and expatriate and repatriate reactions. \\
\hline
\end{tabular}


The research focused on IM rather than international business (IB) - it would therefore be appropriate at this time to note the differences in focus between these two areas, if any. Cavusgil, Knight and Riesenberger (2008:4) define IB as referring to the performance of trade and investment activities by enterprises across national boundaries or as cross-border business, whilst Hodgetts and Luthans (2003:5) define IM as being the process of applying management concepts and techniques in a multinational environment. Contractor (2000:7-8) provides a clearer distinction by stating that the range of interests of the two fields shows a considerable overlap but with a difference in emphasis. IM literature, for the most part, does not focus on the interaction of the enterprise with supranational institutions such as the World Trade Organization and the International Monetary Fund, whilst the IB literature also includes the international aspects of other functional areas such as finance, accounting and marketing, all of which are absent in the IM literature. 'In short, international management is concerned with the management of an international business or multinational corporation' (Kriek et al. 2009:126).

According to Werner (2002:277), IM research can be grouped into three categories:

1. Studies that look at the management of enterprises in a multinational context; this research emphasises the international aspects of management that do not exist in domestic enterprises.
2. Studies that compare the management practices of different cultures (cross-cultural studies) and nations (cross-national studies), also known as comparative management studies.

3. Studies that look at management in a specific nation outside North America (in the context of this research, South Africa) as studies done in other countries are sometimes considered within the domain of IM; also known as foreign domestic studies.

As in the study by Werner (2002:278), this study focused on the first of these categories - pure IM research - and excluded comparative management studies and foreign domestic studies. For the purpose of clarity, each of the 12 IM research topics identified by Werner (2002:277) and used to classify the South African research is described briefly in Table 1.

\section{Results}

As can be seen from the information provided in Table 2, a total of 1313 articles were published in the seven journals between 2004 and 2013. When these articles are compared to the list of IM topics, only 35 can be classified as IM articles, or $2.7 \%$ of the total.

When looking at Table 3, it can be seen that of the 35 IM articles, the largest number, namely eight, were focused on the global business environment, whilst the topic international

TABLE 2: International management articles by journal (2004-2013).

\begin{tabular}{llll}
\hline Journal & Total number of articles & $\begin{array}{l}\text { International management } \\
\text { articles }\end{array}$ & $\begin{array}{l}\text { Percentage of international management } \\
\text { articles per journal (\%) }\end{array}$ \\
\hline Acta Commercii & 110 & 7 & 6.4 \\
Journal of Contemporary Management & 119 & 5 & 4.2 \\
Management Dynamics & 135 & 2 & 1.5 \\
South African Journal of Business Management & 237 & 6 & 2.5 \\
South African Journal of Economic and Management Sciences & 331 & 9 & 2.7 \\
SA Journal of Human Resource Management & 192 & 1 & 0.5 \\
Southern African Business Review & 189 & 5 & 2.7 \\
\hline Total & $\mathbf{1 3 1 3}$ & $\mathbf{3 5}$ & - \\
\hline
\end{tabular}

TABLE 3: International management articles by topic.

\begin{tabular}{|c|c|c|}
\hline Topic & Number of articles & Reference $\dagger$ \\
\hline Global business environment & 8 & $\begin{array}{l}\text { Daya, Ranoto \& Letsoalo (2006); Hwang \& Guo (2006); Jordaan \& Kanda (2011); Kandiero \& } \\
\text { Chitiga-Mabugu (2006); Nyamongo \& Schoeman (2010); Ruggunan (2010); Silvis \& Lessing } \\
\text { (2004); Simon \& Smith (2004) }\end{array}$ \\
\hline Entry-mode decisions & 2 & Marnewick (2012); Saggers (2008) \\
\hline International joint ventures & 1 & Akande \& Banai (2009) \\
\hline Foreign direct investment & 0 & - \\
\hline Transfer of knowledge & 1 & Gorelick \& April (2004) \\
\hline Strategic alliances and networks & 2 & Park \& Hwang (2006); Vögel \& Pires da Cunha (2010) \\
\hline Multinational enterprises & 5 & $\begin{array}{l}\text { Brummer, Badenhorst \& Neuland (2006); Du Bruyn (2005); Horwitz et al. (2005); Van Heerden \& } \\
\text { Barter (2008); Viviers, Muller \& Du Toit (2005) }\end{array}$ \\
\hline Subsidiary-HQ relations & 1 & Khomba, Vermaak \& Gouws (2011) \\
\hline $\begin{array}{l}\text { Subsidiary and multinational team } \\
\text { management }\end{array}$ & 3 & Horwitz, Hemmant \& Rademeyer (2008); Maree (2005); Sales (2006) \\
\hline Expatriate management & 4 & $\begin{array}{l}\text { Swarts \& Du Plessis (2007); Van der Bank \& Rothman (2006); Vögel \& Van Vuuren (2008); Vögel, } \\
\text { Van Vuuren \& Millard (2008) }\end{array}$ \\
\hline
\end{tabular}

35

$\dagger$, Note: For full names of multi-author sources, please see reference list. 
TABLE 4: Number of publications per year (2004-2013).

\begin{tabular}{ll}
\hline Year of publication & Number of articles \\
\hline 2004 & 3 \\
2005 & 5 \\
2006 & 7 \\
2007 & 2 \\
2008 & 8 \\
2009 & 1 \\
2010 & 3 \\
2011 & 4 \\
2012 & 2 \\
2013 & 0 \\
\hline Total & 35 \\
\hline
\end{tabular}

exchange had seven articles and multinational enterprises, five articles. One topic, namely foreign direct investment, was not covered by any article.

Looking at the dates of these publications (see Table 4), it can be seen that there was a decrease in the number of publications since 2009 with only 10 publications between 2009 and 2013, whereas the five years up to 2009 (2004-2008) produced 25 articles.

Lastly, it can be seen from Table 2 that the journal that published the most IM articles was the South African Journal of Economic and Management Sciences. However, when looking at the number of published IM articles as a percentage of the total number of articles published, Acta Commercii leads the field with $6.4 \%$, followed by the Journal of Contemporary Management with $4.2 \%$.

\section{Discussion}

As indicated by Werner (2002:277), as business becomes more global and IM issues play a more central role in business practice, the importance and relevance of IM research increases. This is, however, not the case in South Africa. Not only do the total number of IM articles published in South African management journals - 35 out of 1313 articles - represent a mere $2.7 \%$ of all articles published, but there was a decline in the number of IM articles, from 25 between 2004 and 2008 to 10 between 2009 and 2013. This is at a time when South African enterprises are increasingly becoming more international and playing an increasingly important role, both internationally and in Africa, in particular (South Africa Foundation 2004:6-13; UNCTAD 2004:21-22; 2005:3).

With either no article or, at best, two articles covering the following IM topics, the following seven topics in particular deserve much more research attention:

- Internationalisation.

- Entry-mode decisions.

- International joint ventures.

- Foreign direct investment.

- Transfer of knowledge.

- Strategic alliances and networks.

- Subsidiary-HQ (headquarters) relations.
Particular topics that could receive a great deal more attention, given South African enterprises' presence in Africa, are (Akbar \& Samii 2005:391-392):

- Developing conceptual frameworks for market-entry strategies.

- Managing government-business relationships, given the political peculiarities of emerging markets.

- Developing frameworks for understanding appropriate configuration of the international value chain in emerging markets.

- Prescriptive empirical research focusing on how to implement strategies in emerging markets.

- Privatisation and acquisition strategies for multinational enterprises.

This shortage of South African research supports the finding of Newa and Fillippaios (quoted in Oosthuizen 2005:77), who state that there is a lack of IM research on lesser-developed economies such as South Africa. This means that South African enterprises have to base their internationalisation and international management decisions on research originating predominantly in the USA and Western Europe; and that our tertiary institutions have to rely on research findings from the USA and Western Europe in their IM courses. This generalisation of management theories across countries is, however, not always possible, as found by Vögel and Pires da Cunha (2010:75), a finding supported by both House et al. and Javidan et al. (in Kriek et al. 2009:126-127).

The findings also show that over the last 10 years Acta Commercii has been more open to the publication of South African IM articles, with the highest percentage of its articles focusing on this field.

Lau (2002:174), focusing on the state of Asian management research, stated that management research in Asia has something to offer to the broader body of knowledge, but that the work done has been inadequate, a sentiment worth repeating with regard to IM research in South Africa.

\section{Conclusion}

Although a great deal of IM research has been done over the years, most of it seems to focus on and originate in the USA and Europe and cannot be generalised to multinational enterprises in all countries. As an emerging market, South Africa could be an important testing ground for existing theories, models and concepts of business and management, as well as for the development of new theories in the field of IM. However, even though South African enterprises are increasingly internationalising their operations, a mere $35(2.7 \%)$ of the 1313 articles published in South African management journals over the last 10 years (2004-2013) focused on IM research. There seems to be a shortage in research on all 12 IM topics and the following seven topics in particular have received little or no attention: internationalisation; entry-mode decisions; 
international joint ventures; FDI; transfer of knowledge; strategic alliances and networks; and subsidiary-HQ relations.

By highlighting the lack of IM research in South Africa, this study identified the gaps in this research, which should help future researchers; it also serves as a source of IM information for other researchers looking for sources of South African IM research.

\section{Acknowledgements Competing interests}

The author declares that he has no financial or personal relationship(s) that may have inappropriately influenced him in writing this article.

\section{References}

Akande, W.A. \& Banai, M., 2009, 'Your next boss is American: attitudes of South African managers towards prospective US-South African joint ventures', South African Journal of Business Management 40(2), 1-14.

Akbar, Y.H. \& Samii, M., 2005, 'Emerging markets and international business: A research agenda', Thunderbird International Business Review 47(4), 389-396. http://dx.doi.org/10.1002/tie.20059

Barnard, H., 2008, 'Capability development and the geographic destination of outbound FDI by developing country firms', International Journal of Technology and Globalisation 4(1), 39-55. http://dx.doi.org/10.1504/ IJTG.2008.016186

Brummer, H.L., Badenhorst, J.A. \& Neuland, E.W., 2006, 'An evaluation of the most important competitive analysis methods applied by global mining firms to determine the future intent of a competitive force', Southern African Business Review 10(3), 19-47.

Cavusgil, S.T., Knight, G. \& Riesenberger, J.R., 2008, International business: Strategy, management, and the new realities, Pearson Prentice Hall, Upper Saddle River, NJ.

Contractor, F.J., 2000, 'The raisons d'être for international management as a field of study', Journal of International Management 6(1), 3-10. http://dx.doi. org/10.1016/S1075-4253(00)00017-X

Cuyvers, L., Dumont, M., Viviers, W., De Pelsmacker, P., Muller, M., Jegers, M. et al 2008, 'Export intensity and the competitive intelligence of exporting companies: Evidence from South Africa', South African Journal of Economic and Management Sciences 11(1), 85-97.

Daya, Y., Ranoto, T. \& Letsoalo, M.A., 2006, 'Intra-Africa agricultural trade: A South African perspective', Acta Commercii 6, 99-113.

Department of Higher Education and Training, 2012, South African approved journals, viewed 14 August 2012, from http://www.dhet.gov.za/Structure/Universities/ PolicyandDevelopmentSupport/tabid/416/Itemld/2437/Default.aspx [URL no longer valid].

Du Bruyn, L., 2005, 'The strategy and structure of international business: Ford 2000 (restructuring in a multinational global organisation)' Journal of Contemporary Management 2, 46-56.

Fourie, J., 2011, 'Travel service exports as comparative advantage in South Africa', South African Journal of Economic and Management Sciences 14(2), 210-228.

Fourie, L.C.H., Evans, N. \& Olivier, R., 2007, 'Automated traceability in fruit export chains in South Africa', Southern African Business Review 11(1), 1-22.

Gorelick, C. \& April, K.A., 2004, 'BP case study: KM team structuration and sensemaking (Part 1)', South African Journal of Business Management 35(1), 1-16.

Hodgetts, R.M. \& Luthans, F., 2003, International management: culture, strategy, and behavior, 5th edn., McGraw-Hill, New York.

Holsapple, C.W., Johnson, L.E., Manakyan, H. \& Tanner, J., 1993, 'A citation analysis of business computing research journals', Information \& Management 25(5), 231 244. http://dx.doi.org/10.1016/0378-7206(93)90072-2

Horwitz, M., Ferguson, M., Rivett, I. \& Lee, A., 2005, 'An Afro-Asian nexus: South African multinational firm experiences in Chinese labour markets - key focus areas', South African Journal of Business Management 36(3), 29-40.

Horwitz, F., Hemmant, R. \& Rademeyer, C., 2008, 'Chinese business negotiations: South African firm experiences and perspectives', South African Journal of Business Management 39(1), 1-13.

Hwang, E.G. \& Guo, R., 2006, 'Cultural similarity and international trade in a panel of nations', South African Journal of Economic and Management Sciences 9(2) 213-229.

Jordaan, A. \& Kanda, P., 2011, 'Analysing the trade effects of the EU-SA \& SADC trade agreements: A panel data approach', South African Journal of Economic and Management Sciences 14(2), 229-244.
Kandiero, T. \& Chitiga, M., 2006, 'Trade openness and foreign direct investment in Africa', South African Journal of Economic and Management Sciences $9(3), 355-370$.

Khomba, J.K., Vermaak, F.N.S. \& Gouws, D.G., 2011, 'Redesigning an innovation section of the Balanced Scorecard model: An African perspective', Southern African Business Review 15(3), 1-20.

Klein, S. \& Wöcke, A., 2007, 'Emerging global contenders: The South African experience', Journal of International Management 13(3), 319-337. http://dx.doi. org/10.1016/j.intman.2007.05.002

Kriek, H.S., Beaty, D. \& Nkomo, S., 2009, 'Theory building trends in international management research: an archival review of preferred methods', South African Journal of Economic and Management Sciences 12(1), 126-135.

Lau, C-M., 2002, 'Asian management research: Frontiers and challenges', Asia Pacific Journal of Management 19,171-178. http://dx.doi.org/10.1023/A:1016289700897

Lu, J.W., 2003, 'The evolving contributions in international strategic management research', Journal of International Management 9(2), 193-213. http://dx.doi. org/10.1016/S1075-4253(03)00006-1

Luiz, J.M. \& Charalambous, H., 2009, 'Factors influencing foreign direct investment of South African financial services firms in Sub-Sahara Africa', International Business Review 18(3), 305-317. http://dx.doi.org/10.1016/j.ibusrev.2009.02.008

Maree, S., 2005, 'When in Rome, converse as the Romans do: Effective cross-cultural communication is the bridge between mediocrity and success', Journal of Contemporary Management 2, 57-71.

Marnewick, C., 2012, 'To invest or not to invest in SADC - a project management perspective', Journal of Contemporary Management 9, 341-363.

May, C. \& O'Neill, C., 2008, 'South African export performance: New research into firm-specific and market characteristics', South African Journal of Economic and Management Sciences 11(1), 98-111.

Mpinganjira, M., 2011, 'Perceived impediments to export involvement among small and medium sized firms: Non-exporters' perspective', Acta Commercii Special edition, 43-55.

Nyamongo, M.E. \& Schoeman, N.J., 2010, 'The quality of governance and education spending in Africa', Southern African Business Review 14(2), 1-23.

Oosthuizen, H., 2005, 'The relationship between strategic process dimensions and organisational output performance - a South African investigation in relation to global best practices', South African Journal of Business Management 36(4), 69-79.

Park, S.H. \& Hwang, Y.S., 2006, 'The evolution of alliance formation in biotech firms: An organisational life cycle framework', Management Dynamics 15(4), 40-53.

Peng, M.W. \& Zhou, J.Q., 2006, 'Most cited articles and authors in global strategy research', Journal of International Management 12(4), 490-508. http://dx.doi. org/10.1016/j.intman.2006.04.001

Ruggunan, S., 2010, '(Mis)managing labour markets? The decline of the contemporary global labour market for British seafarers', Acta Commercii 10, 15-26.

Saayman, M., Van der Merwe, P. \& Rossouw, R., 2011, 'The impact of hunting for biltong purposes on the SA economy', Acta Commercii 11, 1-12.

Saggers, G., 2008, 'Vertical mergers: The European guidelines on non-horizontal mergers and their relevance for South Africa', South African Journal of Economic and Management Sciences 11(3), 249-278.

Sales, C., 2006, 'Organisational culture in multinational organisations', Journal of Contemporary Management 3, 60-76.

Shree, S. \& Urban, B., 2012, 'Internationalisation of South African SMEs: The role of capital factors', Acta Commercii 12, 186-199.

Sichei, M.M., Erero, J.L. \& Gebreselasie, T., 2008, 'An augmented gravity model of South Africa's exports of motor vehicles, parts and accessories', South African Journal of Economic and Management Sciences 11(4), 494-510.

Silvis, J. \& Lessing, N., 2004, 'An imminent collapse of the global money system?', Acto Commercii 4, 37-47.

Simon, K.M. \& Smith, N.J., 2004, 'Is disruptive employee behavior in export processing zones (EPZs) influenced by their employment in firms situated in public or private zones?', SA Journal of Human Resource Management 2(1), 45-49. http://dx.doi. org/10.4102/sajhrm.v2i1.31

South Africa Foundation, 2004, South Africa's business presence in Africa, Occasional paper no. 3/2004, viewed 07 December 2007, from http://www.safoundation. org.za/documents/SABusinessPresenceinAfrica_web.pdf

[updated link viewed 17 January 2015, from: http://www.businessleadership.org. za/gup/filez/Occassional_Papers_South_Africa_Business_Presence_in_Africa_ June_2004.pdf]

Swarts, I. \& Du Plessis, Y., 2007, 'Job-related attitudes and expatriates' intention to quit a foreign assignment', Journal of Contemporary Management 4, 46-67.

Tsui, A.S., 2004, 'Contributing to global management knowledge: A case for high quality indigenous research', Asia Pacific Journal of Management 21, 491-513. $\mathrm{http}: / / \mathrm{dx}$.doi.org/10.1023/B:APJM.0000048715.35108.a7

UNCTAD (United Nations Conference on Trade and Development), 2004, World Investment Report 2004: The shift towards services, United Nations, New York and Geneva.

UNCTAD (United Nations Conference on Trade and Development), 2005, Case study on outward foreign direct investment by South African enterprises, viewed 07 December 2007, from http://www.unctad.org/en/docs/c3em26d2a5_en.pdf

UNCTAD (United Nations Conference on Trade and Development), 2013a, Foreign direct investment to Africa increases, defying global trend for 2012, Foreign direct investment to Africa increases, defying global trend for 2012,
viewed 10 March 2014, from http://unctad.org/en/pages/PressRelease. viewed 10 March 2014
aspx?OriginalVersionID $=136$ 
UNCTAD (United Nations Conference on Trade and Development), 2013b World Investment Report 2013. Global value chains: Investment and trade for development, viewed 21 January 2014, from http://unctad.org/en/ for development, viewed 21 Janur.
PublicationsLibrary/wir2013_en.pdf

Van der Bank, M. \& Rothmann, S., 2006, 'Correlates of expatriates' cross-cultural adjustment', Management Dynamics 15(4), 29-39.

Van Eldik, S. \& Viviers, W., 2005, 'The measurement of export readiness of companies in South Africa', Southern African Business Review 9(2), 1-11.

Van Heerden, C.H. \& Barter, C., 2008, 'The role of culture in the determination of a standardized or localized marketing strategy', South African Journal of Business Management 39(2), 37-44.

Viviers, W., Muller, M. \& Du Toit, A., 2005, 'Competitive intelligence: An instrument to enhance South Africa's competitiveness', South African Journal of Economic and Management Sciences 8(2), 246-254.
Vögel, A.J. \& Pires da Cunha, G.B.L., 2010, 'The advantages and pitfalls of South AfricaAngola strategic alliances', Acta Commercii 10, 73-88.

Vögel, A.J. \& Van Vuuren, J.J., 2008, 'Factors influencing the preparation, support and training of South African expatriates', Acta Commercii 8, 80-89.

Vögel, A.J., Van Vuuren, J.J. \& Millard, S.M., 2008, 'Preparation, support and training requirements of South African expatriates', South African Journal of Business Management 39(3), 33-40.

Werner, S., 2002, 'Recent developments in international management research: A review of 20 top management journals', Journal of Management 28(3), 277-305. http://dx.doi.org/10.1177/014920630202800303

Wöcke, A. \& Klein, S., 2009, 'The protective incubator and the growth of South African multinationals', Thunderbird International Business Review 51(4), 341-354. http://dx.doi.org/10.1002/tie.20271 